\title{
BEING OLD AND BEING A WOMAN: A RESEARCH ON THE AGE AND GENDER RELATIONSHIP IN THE AWARD-WINNING ACTORS AND ACTRESSES OF THE TURKISH CINEMA
}

\author{
Melis OKTUĞ ZENGİN \\ melisoktug@gmail.com
}

\begin{abstract}
According to the World Health Organization data, proportion of elderly individuals to total population is going to exceed that of children and youth in about 50 years. In the aging population, proportion of females is higher than the proportion of males. Researches show that women are to face numerous problems resulting from discriminatory practices based on age besides gender pattern in social and economic life. In this study, the discriminatory practices that the aging female population was exposed to in professional life were addressed within the cinema sector. Sample of the research consists of actors and actresses who have received awards in the branches of best actress, best actor, best supporting actress and best supporting actor in the longest-running film festival of Turkey, Antalya Golden Orange Film Festival, since the beginning of the festival. Receiving an award is an indicator of successful performance for cinema actors and actresses. In this context, the role of age and gender in professional careers of cinema actors and actresses was investigated by descriptive statistics method, on the basis of age distribution with respect to the gender of cinema actors and actresses who have received awards in best actress, best actor, best supporting actress and best supporting actor since the beginning of Antalya Golden Orange Film Festival.Results obtained from the study revealed similarities to researches related to actresses in the American Cinema which is a part of the literature. Research findings show that the mean age of award-winning actors is higher than the mean age of award-winning actresses in all the branches under consideration and that women receive awards at younger ages compared to men. In this context, it can be suggested that sexist approaches give rise to double jeopardy for actresses in advanced age and their professional careers are constricted in their old age.
\end{abstract}

Keywords: Discrimination, Age Discrimination, Cinema.

\section{YAŞLI VE KADIN OLMAK: \\ TÜRK SINEMASINDA ÖDÜL ALAN OYUNCULARDA YAŞ VE CINSIYYET İLIŞKISII ÜZERINE BİR ARAȘTIRMA}

\begin{abstract}
ÖZET
Dünya Sağlık Örgütü'nün verilerine göre, yaklaşık 50 yıl kadar bir süre içinde dünyada yaşlı bireylerin toplam nüfusa oranı çocuk ve gençlerin oranını aşacaktır. Yaşlanan nüfusta kadınların oranı, erkeklerden daha yüksektir. Araştırmalar, kadınların, toplumsal ve ekonomik yaşamda, cinsiyet kalıplarının yanısıra yaş temelli ayrımcı uygulamalardan kaynaklanan birçok sorunla yüzyüze kalacağını göstermektedir. Bu çalışmada, yaşlanan kadın nüfusun iş yaşamında maruz kaldığı ayrımcı uygulamalar, sinema alanında ele alınmıştır. Araştırmanın örneklemi, Türkiye'nin en uzun soluklu film festivali olan Antalya Altın Portakal Film Festivali'nde başlangıcından bu yana en iyi kadın oyuncu, en iyi erkek oyuncu, en iyi yardımcı kadın oyunucu ve en iyi yardımcı erkek oyuncu dallarında ödül alan aktör ve aktrislerden oluşmaktadır. Sinema oyuncuları için ödül almak, başarılı performansın bir göstergesidir. Bu bağlamda, sinema oyuncularının mesleki kariyerlerinde, yaş ve cinsiyetin rolü, Antalya Altın Portakal Film Festivali'nde başlangıcından bu yana en iyi kadın oyuncu, en iyi erkek oyuncu, en iyi yardımcı kadın oyunucu ve en iyi yardımcı erkek oyuncu ödülünü alan sinema oyuncularının cinsiyete göre yaş dağılımlarından yola çıkarak betimleyici istatistik yöntemiyle
\end{abstract}


araştırılmıştır. Çalışmadan elde edilen sonuçlar, literatürde yer alan, Amerikan Sineması'nda kadın oyuncularla ilgili araştırmalarla benzerlik göstermektedir. Araştırmanın bulguları, ödül alan erkek oyuncuların yaş ortalamasının kadın oyuncuların yaş ortalamasından değerlendirmeye alınan tüm dallarda daha yüksek olduğunu ve kadınların erkeklere oranla daha genç yaşlarda ödül aldıklarını göstermektedir. Bu bağlamda, cinsiyetçi yaklaşımların ileri yaşlardaki kadın oyuncular için çifte rizikoya (double jeopardy) yol açtığı, mesleki kariyerlerinin ileri yaşlarda kısıtlandığ söylenebilmektedir.

Anahtar kelimeler: Ayrımcılık, Yaş Ayrımcılı̆̆

\section{INTRODUCTION}

According to the World Health Organization data, the proportion of elderly population will have reached a higher percentage than that of the children in 0-14 age group in as soon as 50 years' time and for the first time in history (World Health Organization [WHO], 2007: 3). The fact that proportion of the elderly population to total population is gradually increasing and life span is extending indicates that several generations are going to coexist in the near future. Therefore intergenerational relationships will become even more important in the coming years (Pellisier, 2009: 5).

Population aging in our day is characterized as the greatest social change taking place in the world (WHO, 2012: 10). Policy proposals that can be developed in the face of this great change are being discussed in the international platform; the World Health Organization [WHO] (Organization Mondiale de la Sante [OMS]) which is a specialized agency of the United Nations [UN], the United Nations Population Fund [UNFPA] and the International Labour Organization [ILO] and also the related commissions of the European Union [EU] (Union Européenne [UE]) are working on the subject of elderliness and aging. Problems in regard to population aging were first brought up to the world agenda in the UN World Assembly on Aging (1982) (UN, 1983). As for the European Union, it determined its action plan regarding the possible results of a rapidly aging population in the early 1990s. Relevant organizations emphasize the significance of the social aspect of the issue as strongly as the significance of the economic aspect, in the policies to be developed in the face of the aging world (Union Européenne, 2012).

In this study, the phenomenon of elderliness and aging is addressed within the scope of discrimination in professional life. Age discrimination causes more negative outcomes especially in the case of women. Discriminatory practices brought by gender pattern on the one hand and inequality resulting from age discrimination on the other, lead up to double jeopardy for women. The role of age and gender in the professional careers of cinema actors and actresses was investigated by descriptive statistics method, on the basis of age distribution with respect to the gender of cinema actors and actresses who have received awards in best actress, best actor, best supporting actress and best supporting actor since the beginning of the Antalya Golden Orange Film Festival.

\section{WORLD'S NEW DEMOGRAPHIC OUTLOOK: THE AGING WORLD}

Population structure has gone through a significant change in the world; the elderly population has increased as death and birth rates have declined (United Nations [UN], 2007). Population aging is considered especially as the problem of developed countries since welfare levels are higher in these countries. Yet the myth about the grand majority of elderly population living in developed countries is fading away. In the second quarter of the century, the elderly population in developing countries is expected to be two times more than the elderly population in developed countries (HelpAge, 2011). Population structure in Turkey too undergoes a change similar to the overall picture in the world. Percentage of the elderly population consisting of individuals aged 65 and older was 7.7 in the year 2013. Population projections propound that this percentage will reach 10.2 per cent in the year 2023 and 20.8 per cent in the year 2050. In other words, it is estimated that Turkey too will be among the countries with very elderly population in the near future (TUİK, 2014, İstatistiklerle Yaşl1lar, 2013).

The aspect of population aging in regard to females is worthy of consideration because females constitute the majority of the elderly population (Samorodov, 1999: 3). Life expectancy at birth for 
females is 4.5 years longer compared to that of males in the world. Thus, grand majority of the 80plus age group which is defined as "old old" are women. In underdeveloped countries where motherchild death rates were high and women were also disadvantaged in issues like access to nutrition and healthcare services, life expectancies at birth for women and men were close to each other until very recently. Yet in the recent years, thanks to the progresses made, life expectancy at birth for females in underdeveloped countries has exceeded the life expectancy at birth for males, as is the case in developed countries (Zahidi, 2012: 21). It can be stated that life expectancy at birth for women in Turkey is close to the world average. According to the Turkish Statistical Institute [TurkStat] (Türkiye İstatistik Kurumu [TUIKK]) (2012) data, life expectancy at birth for females is 79.2 whereas it is 74.7 for males.

Population aging has both economic and social consequences. In social terms, it has influence over family structure and life styles. Economic aspect of the issue on the other hand, would manifest itself in the medical and social security expenditures that would emerge depending on the increasing proportion of elderly population to the population as a whole (Samorodov, 1999: 4). The economic and social consequences to be caused by population aging would also bring about some important consequences with regards to women. With modern societies changing from extensive family to nuclear family structure, women with the probability of living longer than their spouses are to become isolated according to demographic data. In economic terms, they are to face the problem of poverty more severely than men since women take part in the professional life less than men do (Dupâquier, 2006). Population aging that emerges in parallel with life span extension is considered as one of the greatest victories of humanity. However this victory also necessitates restructuring policies in the whole world according to socioeconomic requirements of the aging world (WHO, 2002: 4).

\section{AGE PHENOMENON AND WOMAN}

While addressing the age phenomenon, some physical and biological characteristics, gender, psychological state, social environment in which one lives, economic conditions that are particular to the individual may play a part whereas the culture and society in which one lives are also effective on this picture. There are right times determined by both laws and regulations depending on chronological age as well as in social terms, for rights and restrictions such as starting school, getting a driver's license, getting married or being elected as president of the republic.

Every society uses categories of gender and age to classify its members (Palmore, 1999: 5). The fields where social classification is mostly seen are gender, ethnic features and age. Age is a factor that determines the status and social relations of a person in every society, in a fashion similar to the other categories (Neugarten cited by Macnicol, 2006: 5). Age can play an important role in our behaviours and decisions as well (Cuddy \& Fiske, 2004, s.3). In this context, it is not only a chronological or biological phenomenon but also a social reality. The society and epoch one lives in are influential on definitions regarding age (Onur, 2011:23).

For women, age bears a different meaning compared to the one it does for men. According to Sontag (1972), although both man and woman pass through the same periods such as young adulthood, adulthood and elderliness, women are faced with double standard when the age is in question, as is the case with unfaithful man. This is due to society's outlook on woman and man. Society attributes more negative characteristics to an aging woman than it does to an aging man. Men have characteristics such as skills, freedom and self-sufficency that further develop as they get older, let alone disappear. On the other hand, beauty and attractiveness come to the fore as fundamental elements that define womanhood and these features disappear with age. Thus woman adopts a more defensive attitude that rejects her real age (Sontag, 1972: 31). Another disadvantage that women

1 As lifespan extended, necessity of classifying the individuals included in the 65-plus age group arose. Nowadays, the elderly are addressed in two groups named as young old (in the 65-74 age group) and old old (75-plus). Moreover, periods defined as third and fourth life are mentioned (Tufan, İ. (2003). Modernleşen Türkiye'de Yaşl1lık ve Yaşlanmak. İstanbul: Anahtar, 57) 
experience is that they age faster than men. There is a perception about the aging process starting earlier in women (Sontag, 1972: 32).

The fact that beauty and attractiveness are at the forefront among qualities attributed to women in the society causes physical appearance to be evaluated with a different perspective by women and men. Whereas white hair and facial wrinkles are associated with maturity and experience in the case of men, women can gain value only by their young looks (De Pater \& Judge \& Scott, 2014: 4). Youth ideal is a norm that contemporary Western societies have determined for women (Sontag, 1972; Saucier, 2004). According to Macnicol (2006) the desire to be forever young is the fetish of modern societies and extensive usage of methods like botox or anti-aging cosmetic products presented to the society as youth elixir actually proves how strong this ideal is. The youth ideal that dominates the western culture emerges as a factor that fuels age discrimination especially in women, in terms of encouraging people to remove age related traces and accordingly developing the negative perspective on the elderly (Nelson, 2011:41).

\section{DISCRIMINATION ON THE BASIS OF AGE AND MULTIPLE DISCRIMINATION}

Discrimination means treating a person differently than other people in a similar state and conditions, with no public interest or any valid reason (Çelenk, 2010: 211). Discrimination is observed in various areas such as gender, race, ethnic origin, religion, faith, disability and sexual orientation. Treating individuals differently just due to their age without any valid justification is defined as age discrimination (HelpAge International, 2011).

Age discrimination appears in direct and indirect forms as is the case in other types of discrimination. Direct discrimination is excluding or preferring individuals in laws or practices, because they are the members of a certain social group. Including age limitation in the application requirements in job adverts can be stated to exemplify this. Indirect discrimination on the other hand, can be defined as rules and operations that influence a group in practice although it appears to be unbiased. Within this context, excluding some employees from professional seminars due to their age is a practice of indirect discrimination (Baybora, 2010: 36-37).

It can be suggested that age discrimination is differentiated from other types of discrimination in terms of both social policies and researches being conducted in various disciplines finding less place in the world agenda (Smeaton \& Vegeris, 2009: 3). Another point that differentiates this type of discrimination, for instance when compared to a type of discrimination such as racism, is that age discrimination can be tolerated much more easily (Lagacé, 2010:3).

Discrimination on the basis of age emerges rarely with respect to age alone. Most of the time, it causes discriminatory practices whose impact increases with numerous factors coming together (HelpAge, 2011). Interaction of discrimination types or someone's exposure to different discrimination practices in various areas engenders multiple discrimination (discrimination on multiple grounds, intersectional discrimination) (Gül \& Karan, 2011: 21). Someone being black, a woman and an elderly or both a woman and disabled can be given as an example of multiple discrimination.

Social scientists have studied the interaction of discrimination types emerging in different social categories. It was specified that the negative impact caused by multiple categories at once was higher than that of any category by itself. The disadvantage resulting from multiple categories has been explained by the concept of double jeopardy in the works on discriminatory practices which those who are both woman and black were exposed to in areas of racism and sexism. According to this, the disadvantage resulting from individuals' exposure to racist and sexist practices in social and economic life, is more effective in the interaction of these two categories than the sum of negative attitudes emerging in each category (Lincoln \& Allen, 2004: 611-612). Chappell \& Havens (1980) addressed the validity of the concept of double jeopardy used within the scope of racism and sexism in terms of age and gender. Results obtained from the research proved that individuals who were both elderly and female were more disadvantaged than individuals who were both elderly and male. In this context, it 
can be suggested that gender patterns that render women disadvantaged have a sronger effect when combined with negativities resulting from age discrimination in advanced ages.

\section{AGE-BASED AND GENDER-BASED DISCRIMINATION IN THE CAREERS OF CINEMA ACTORS AND ACTRESSES}

Acting in cinema is one of the areas where multiple discrimination related to gender and age emerges. In the cinema, discriminatory practices that actors and actresses might encounter are approached from two different perspectives. First one is the income inequality between actors and actresses. Second one is the frequency of female and male characters showing up in lead and supporting roles. In other words, it is rendering some social groups invisible as is the case in other types of discrimination.

When the issue is addressed in terms of income equality between genders, no difference is seen between the incomes of actresses and actors in the American Cinema in 1940s when studio system was dominant. Moreover, long-term contracts made with stars in the Hollywood studio system ensured that professional careers of cinema actors and actresses were guaranteed for a long period of time (De Pater \& Judge \& Scott, 2014). As adventure movies started to dominate Hollwood since the 1970s instead of genres such as romantic melodramas and musicals, number of movies like Jaws (director: Steven Spielberg, 1975) where mostly male characters were seen, increased. In this context, both the visibility of actresses decreased in the cinema and the income balance between actors and actresses was disturbed (Lincoln \&Allen, 2004:615). Today, researches show that actresses, especially elderly actresses appear in lead roles less than actors (Bazzini, McIntosh, Smith, Cook \& Harris, 1997). According to Saucier (2004), the women in advanced ages to be less visible not only limit their job opportunities but also eliminate possible elderly role models for young women.

When the incomes of actresses and actors are compared with respect to age and gender, women, and especially middle-aged and elderly women are seen to lag behind men. In the list of Hollywood's highest-paid cinema actors and actresses of 2013, Jennifer Lawrence (23) takes the first place due to her success in the movie Hunger Games: Catching Fire (director: Francis Lawrence, 2013). The only middle-aged actress who ranks among the list is Sandra Bullock (49). On the other hand, actors at various ages such as Vin Diesel (46), Diesel Steve (51), John Goodman (61) and Billy Crystal (66) ranked among the same list (http://www.beyazperde.com/dosyalar/sinema/dosya-50773/).

In the conference "VintAge 2001: Positive Solutions to an Age-Old Problem" carried out in America in 2001, the term "silver ceiling" was proposed to refer to age discrimination in the entertainment industry. This term is used particularly for actresses. Whereas actors in their sixties such as Jack Nicholson and Harrison Ford can be seen in romantic affairs with women younger than themselves in the movies, elderly actresses take less part in the movies and they generally play women with no attractiveness and love life (Saucier, 2004: 421).

The fact that visibility of elderly actresses in cinema is low and they lag behind elderly actors in terms of income, support the view that women gain value only when they are young. In this context, the actresses in cinema face double jeopardy in their professional careers due to both sexist approaches and age discrimination.

\section{RESEARCH \\ RELATED LITERATURE}

Age discrimination is seen to emerge in two distinct levels. First one is the representative level that includes the prejudices and stereotypes regarding the elderly. The other one is the active level that refers to the behavioural aspect of age discrimination as in professional life (Pilote, 2010:6; Rochman $\&$ Tremblay, 2010: 5). Grand majority of the studies carried out in the media field regarding age discrimination is about the representative aspect of the issue. Representations and stereotypes of the elderly have been the research subject in various communication media such as television (Cohen, 2002; Gerbner, 1994; Harwood, 2000; Rahtz, Sirgy \& Meadow, 1989; Roy \& Harwood, 1997; Signorielli, 2004), printed media (Almerico \&Thompson,1989; Sedick \& Roos, 2011), animation movies (Robinson \& Anderson, 2006; Robinson, Callister, Magoffin, Moore, 2007) and 
advertisement (Peterson, 1992; Zhang, Harwood, Williams, Ylanne-McEven, Wadleigh, Thimm, 2006). While researches regarding the elderly representations center especially upon the television field, there is a limited number of studies that address the elderly stereotypes in the cinema (Markson \& Taylor, 2000).

Although there is a great number of studies that research the active level of age discrimination in professional life in the literature, the number of studies that addresses age and gender related discriminatory practices in professional careers of cinema actors and actresses in terms of double jeopardy is rather limited (Lincoln \& Allen, 2004).

De Pater, Judge \& Scott (2014) researched the effect of age and gender on the incomes of Hollywood stars and found that incomes of actresses rise until they are 34 years old and start to fall rapidly in the following years whereas actors' incomes reach maximum at the age 51 and remain constant in the following years.

Lincoln \& Allen (2004) researched the frequency of 40-plus actresses playing parts in the movies in the period between right before sound films, namely 1926 and 1999, with respect to age and gender correlation. According to the results obtained from the research, as the ages of actresses advance, their possibility of playing a part in the movies decrease in comparison to men.

Lauzen (2013) investigated 7,000 movie characters in her research which was based on movies that succeeded in the box office and discovered that actresses were younger than their male partners and actors played more main characters than actresses. Majority of female characters are in their 20's (26 per cent) and 30's (28 per cent). On the other hand, male characters are mostly in their 30 's ( 27 per cent) and 40's (31 per cent). 40-plus female characters constitute 30 per cent of total female characters whereas this ratio is 55 per cent for the male characters.

Markson \& Taylor (1993) addressed the age and gender factors within the framework of awardwinning actors and actresses in the cinema. Their research sample consisted of 1,169 actors and actresses who were nominated and received awards for best actress, best actor, best supporting actress and best supporting actor in the Academy Awards between the years 1927 and 1990. It was discovered that only 27 per cent of the actresses were above 39 years old whereas this ratio was 67 per cent in the actors. Moreover, they found that award-winning actresses were 8 years younger than the actors whereas the best supporting actresses were 7 years younger. Markson \& Taylor (1993) concluded in this study that actresses in the film sector were considered elderly after 35 and their professional career was limited after this age. In this context, women are considered worth receiving awards only when they are young.

Studies in the relevant literature show that actresses in Hollywood have high incomes in their youth, their professional careers are shorter than men and they receive awards when they are young.

\section{OBJECTIVE AND METHOD}

The objective of this research is to propound the relationship of age and gender factors with the professional careers of actresses in the Turkish Cinema. Both in the world and Turkey, awards given to actors and actresses in important festivals are indicators of their successful performance. In this context, it is important in terms of their professional career. In the study, age distribution of actors and actresses who have received awards since the beginning of Antalya Golden Orange Film Festival were examined with respect to the categories of best actress, best supporting actress, best actor and best supporting actor.

Actors and actresses who have received awards in the oldest and the longest-running film festival in Turkey, Antalya Golden Orange Film Festival were chosen to constitute the research sample. The festival was first realized in 1964 and gained international status in 2005. Antalya Golden Orange Film Festival could not take place only in the years 1979 and 1980. Yet the awards of these years were handed over to their owners after 30-31 years (http://www.altinportakal.org.tr/festival/festival- 
tarihcesi/). In this context, the sample consisting of award-winning actors and actresses in the festival in question enabled the formation of a data repository where professional career of the actors and actresses within the historical development of Turkish cinema could be evaluated with respect to age and gender relationship.

The sample consists of 51 actresses who won the best actress award, 54 actors who won the best actor award, 51 actresses who won the best supporting actress award and 55 actors who won the best supporting actor award in the Antalya Golden Orange Film Festival between the years 1964 and 2013, adding up to 211 actors and actresses in total. In 2010 and 2012, two foreign actresses received the best supporting actress awards in the festival. Since the relationship of age and gender with the professional career of actresses in the Turkish cinema is studied in the research, Claudia Cardinale who won the award in 2010 with Being Italian with Signora Enrica (director: Atilla İlhan, TurkishItalian co-production) and Anna Andurusenco who won the award in 2010 with Farewell Katya (director: Ahment Sönmez) were excluded from the sample. Also Inge Keller who won the best supporting actress award in 1999 with the movie Lola and Billy the Kid (director: Kutlug Ataman) was not included in the sample. Ages of the cinema actors and actresses were obtained by reviewing online film sources and movie magazines. Among the award-winning actors and actresses, only the birth date of Zuhal Gencer who won the best actress award with The Eighth Hour (director: Cemal Gözütok) could not be found, thus Gencer too was omitted from the sample.

Age, as indicated earlier, is a phenomenon defined with its social, psychological and societal aspects. Within the scope of the study, age was addressed only with its chronological aspect, in other words with respect to chronological age. 65 years of age which is the age active professional life is complete and retirement starts in many countries in the world is considered as the beginning of elderliness (World Health Organization [WHO], 1972: 11). The United Nations takes 60 years of age and above into consideration in studies regarding elderliness (UNFPA\& HelpAge International, 2012: 20). Studies in the literature show that professional careers of actresses are particularly shorter in comparison to actors, and actresses receive awards at younger ages compared to men. Therefore, the beginning of elderliness in this study was determined as 60 , in accordance with the classification of the United Nations.

In the research, 60 years old and older actors and actresses who have received awards in the Antalya Golden Orange Film Festival were specified; mean ages of actors and actresses who have received awards in the categories of best actress, best actor, best supporting actress and best supporting actor were compared with respect to both decades and award categories.

In this study, method of descriptive statistics was used. Descriptive statistics is a method that provides benefits to the researcher in cases where there is quantization (Karasar, 2007: 207) and enables collective evaluation of general view of raw data that comes out (Geray, 2006: 92). SPSS software package was used in data analysis and finding the calculated values.

Answers to the questions below were searched for in the study:

1. In the fifty-year period of Antalya Golden Orange Film Festival, how many 60 years old and above actors and actresses have received awards in the best actress, best actor, best supporting actress and best supporting actor categories so far?

2. What is the distribution of mean ages of actors and actresses who have received awards in the best actress, best actor, best supporting actress and best supporting actor categories in the festival between 1964 and 2013, with respect to decades?

3. Is there a significant difference between best actresses and best supporting actresses in terms of their age?

4. Is there a significant difference between best actresses and best actors in terms of their age?

5. Is there a significant difference between the best supporting actress and best supporting actor in terms of their age? 


\section{FINDINGS}

Actors and actresses who have received awards in the best actress, best actor, best supporting actress and best supporting actor categories between the years 1964 and 2013 in the Antalya Golden Orange Film Festival were investigated in order to specify the ones who fall into the elderly category according to UN's classification in terms of chronological ages.

\begin{tabular}{|c|c|c|c|c|}
\hline $\begin{array}{l}\text { Date of } \\
\text { Receiving } \\
\text { Award }\end{array}$ & $\begin{array}{l}\text { Title of the Movie that } \\
\text { Received Award }\end{array}$ & $\begin{array}{l}\text { Award-winning } \\
\text { Actor/Actress }\end{array}$ & Award Category & $\begin{array}{l}\text { Age of the } \\
\text { Award-winning } \\
\text { Actor/Actress }\end{array}$ \\
\hline 1969 & $\begin{array}{l}\text { Bin Yillık Yol (A } \\
\text { Thousand-year Road) }\end{array}$ & Muazzez Arçay & Best supporting actress & 62 years old \\
\hline 1980 & Düşman (The Enemy) & Fehamet Atilla & Best supporting actress & 80 years old \\
\hline 1995 & Gerilla (The Guerrilla) & Tomris Oğuzalp & Best supporting actress & 63 years old \\
\hline 2000 & $\begin{array}{l}\text { Renkli Türkçe (Colored } \\
\text { and in Turkish) }\end{array}$ & Nilüfer Aydan & Best supporting actress & 60 years old \\
\hline 2010 & Kă̆glt (Paper) & Ayşen Gruda & Best supporting actress & 65 years old \\
\hline 1994 & $\begin{array}{l}\text { Yengeç Sepeti (The } \\
\text { Crab Basket) }\end{array}$ & Sadri Alışık & Best actor & 69 years old \\
\hline 2005 & $\begin{array}{l}\text { Gönül Yarası } \\
\text { (Lovelorn) }\end{array}$ & Şener Şen & Best actor & 64 years old \\
\hline 2000 & Güle Güle (Bye Bye) & Şükran Güngör & Best supporting actor & 74 years old \\
\hline 2001 & $\begin{array}{l}\text { Büyük Adam Küçük } \\
\text { Aşk (Big Man, Little } \\
\text { Love) }\end{array}$ & İsmail Hakkı Şen & Best supporting actor & 74 years old \\
\hline 2003 & $\begin{array}{l}\text { Abdülhamit Düşerken } \\
\text { (The Fall of } \\
\text { Abdulhamit) }\end{array}$ & Çetin Öner & Best supporting actor & 60 years old \\
\hline 2004 & Yazı Tura (Toss-Up) & Bahri Beyan & Best supporting actor & 70 years old \\
\hline 2007 & $\begin{array}{l}\text { Yaşamın Kıyısında } \\
\text { (The Edge of Heaven) }\end{array}$ & Tuncel Kurtiz & Best supporting actor & 71 years old \\
\hline
\end{tabular}

Table 1: 60-plus award-winning actors and actresses

According to Table 1, it was detected that there was no 60-plus actress who has won an award in the best actress category. It was specified that only five 60-plus actresses have won the best supporting actress award among a total of 51 awards given out in the fifty-year period between 1964 and 2013 in the festival. Despite the fact that there was no 60-plus actress who has won the best actress award, there were two 60-plus actors who have won the best actor award among 54 actors in total. Five 60plus actors were granted the best supporting actor award among 55 award winning actors in total in this category, as was the case in the best supporting actress.

\begin{tabular}{|l|l|l|l|l|}
\hline \multirow{3}{*}{ Years } & Best Actress/Actor & Best Supporting Actress/Actor \\
\cline { 2 - 5 } & Female & Male & Female & Male \\
\cline { 2 - 5 } & $\mathrm{N}$ & $\mathrm{N}$ & $\mathrm{N}$ & $\mathrm{N}$ \\
\hline $1960 \mathrm{~s}$ & 6 & 6 & 6 & 6 \\
\hline $1970 \mathrm{~s}$ & 10 & 10 & 10 & 10 \\
\hline $1980 \mathrm{~s}$ & 11 & 11 & 10 & 10 \\
\hline $1990 \mathrm{~s}$ & 10 & 12 & 15 & 11 \\
\hline $2000 \mathrm{~s}$ & 14 & 15 & 51 & 18 \\
\hline $\begin{array}{l}\text { From } 1960 \mathrm{~s} \\
\text { to date }\end{array}$ & 51 & 54 & 55 \\
\hline
\end{tabular}

Table 2: Distribution of the numbers of best actress, best actor, best supporting actress and best supporting actor with respect to decades 


\begin{tabular}{|l|l|l|l|l|l|l|l|l|}
\hline \multirow{3}{*}{ Years } & \multicolumn{4}{|l|}{ Best Actress/Actor } & \multicolumn{3}{l|}{ Best Supporting Actress/Actor } \\
\cline { 2 - 9 } & Female & \multicolumn{2}{|l}{ Male } & Female & \multicolumn{3}{l|}{ Male } \\
\cline { 2 - 9 } & Mean & $\begin{array}{l}\text { Std. } \\
\text { Deviation }\end{array}$ & Mean & $\begin{array}{l}\text { Std. } \\
\text { Deviation }\end{array}$ & Mean & $\begin{array}{l}\text { Std. } \\
\text { Deviation }\end{array}$ & Mean & $\begin{array}{l}\text { Std. } \\
\text { Deviation }\end{array}$ \\
\hline $1960 \mathrm{~s}$ & 21,33 & 2,34 & 45,5 & 2,25 & 32,33 & 9,20 & 40,17 & 5,78 \\
\hline $1970 \mathrm{~s}$ & 28,80 & 8,28 & 30,30 & 8,10 & 33,40 & 6,38 & 42,60 & 7,29 \\
\hline $1980 \mathrm{~s}$ & 31,73 & 5,18 & 39,82 & 6,49 & 40,80 & 15,48 & 39,40 & 9,48 \\
\hline $1990 \mathrm{~s}$ & 34,10 & 8,42 & 43,42 & 13,20 & 42,60 & 14,10 & 47,82 & 10,16 \\
\hline $2000 \mathrm{~s}$ & 30,79 & 7,25 & 37,00 & 12,68 & 39,00 & 12,30 & 49,12 & 17,80 \\
\hline $\begin{array}{l}\text { From 1960s } \\
\text { to date }\end{array}$ & 30,14 & 7,7 & 37,82 & 10,45 & 39,12 & 12,85 & 44,93 & 12,75 \\
\hline
\end{tabular}

Table 3: Mean ages with respect to categories in decades

When the mean ages of actors and actresses who have received awards in the best actress, best supporting actress, best actor and best supporting actor categories in the Antalya Golden Orange Film Festival are taken into consideration with respect to decades, the lowest mean age for all actors and actresses (21 years) is seen to have emerged in 1960s in the best actress category. The highest mean age (49 years) on the other was seen in 2000 s in the best supporting actor category.

The highest mean age in the best actress category (34 years) was reached in 1990s. Today, when we look at 2000s, the mean age of best actresses was 31. The mean age of actresses who have received the best actress award since 1960 s until today is 30 years.

Whereas the lowest mean age in the best actress category was seen in the early years, the highest mean age in the best actor category was also seen in this period ( 45.5 years). The lowest mean age in the best actor category (30 years) was in 1970s. In 2000s, mean age of the actors who received awards in the same category is 37 years. The mean age of the actors who have received the best actor award since the beginning of the festival until today is 38 years.

The lowest mean age in the best supporting actress category was seen in the early years of the festival (32 years). The highest mean age in this category (43 years) was reached in 1990s. Today, the mean age of actresses who received the best supporting actress award in 2000s is 39 years. Since 1960s which is the beginning of the festival to date, the mean age in the same category is specified to be 39 years.

The lowest mean age in the best supporting actor category (39 years) was seen in 1980s. The highest mean age was reached in 2000s (49 years). The mean age of actors who have won the best actor award since the beginning of the festival is 45 years.

\begin{tabular}{|l|l|l|l|l|l|}
\hline & $\mathrm{N}$ & Mean & Std. Deviation & $\mathrm{t}$ & $\mathrm{p}$ \\
\hline Best actress & 51 & 30,1373 & 7,62370 & \multirow{2}{*}{$-4,294$} & \multirow{2}{*}{, 000} \\
\cline { 1 - 4 } Best supporting actress & 51 & 39,1176 & 12,84313 & & \\
\cline { 1 - 5 } & & & & \\
\hline
\end{tabular}

Table 4: Comparison of mean ages of best actresses and best supporting actresses

With reference to Table 4, it can be suggested that there is a significant difference between the mean ages of best actresses and best supporting actresses $(\mathrm{p}<.001)$.

\begin{tabular}{|l|l|l|l|l|l|}
\hline & $\mathrm{N}$ & Mean & Std. Deviation & $\mathrm{t}$ & $\mathrm{p}$ \\
\hline Best actress & 51 & 30,1373 & 7,62370 & \multirow{2}{*}{$-4,319$} & \multirow{2}{*}{, 000} \\
\cline { 1 - 5 } & & 37,8148 & 10,44676 & & \\
\hline
\end{tabular}

Table 5: Comparison of the mean ages of best actresses and best actors 
According to Table 5, it can be suggested that there is a significant difference between the mean ages of best actresses and best actors $(\mathrm{p}<.001)$.

\begin{tabular}{|l|l|l|l|l|l|}
\hline & $\mathrm{N}$ & Mean & Std. Deviation & $\mathrm{t}$ & $\mathrm{p}$ \\
\cline { 1 - 4 } Best supporting actress & 51 & 39,1176 & 12,84313 & \multirow{2}{*}{$-2,336$} & \multirow{2}{*}{, 021} \\
\cline { 1 - 4 } Best supporting actor & 5 & 44,9273 & 12,74371 & & \\
\hline
\end{tabular}

Table 6: Comparison of mean ages of best supporting actresses and best supporting actors

With reference to Table 6 , it can be suggested that there is a significant difference between the mean ages of best supporting actresses and best supporting actors $(\mathrm{p}<.05)$.

\section{CONCLUSION}

The effect of gender and age factors on the professional careers of actresses in the cinema was examined in this study. With this object in mind, actors and actresses who have received awards in the best actress, best actor, best supporting actress and best supporting actor categories in the Antalya Golden Orange Film Festival were evaluated with reference to their chronological age. 60-plus actors and actresses who have received awards in the categories in question since the beginning of the festival to this day were specified and mean ages for each decade was calculated.

According to the results obtained from the study, there is no 60-plus actress who has received a best actress award. Only two 60-plus actors have received the best actor award. It was discovered that actresses above 60 years of age could not win awards for leading roles but could only win the best supporting actress award.

When the mean ages in the best actress category are considered in ten-year periods, the mean can be suggested to have risen until 1990s and declined in 2000s. Mean age of the actresses who have received the best actress award in the festival so far is 30 years.

In the distribution of mean ages of actors who have received the best actor award with respect to decades, it can be suggested that in the decades except 1970s which includes the lowest mean, actors who were in their 40 s or close to middle-age received awards. There is no actress from this age group who has received an award in the best actress category.

It was observed that actresses were not able to win the best actress award in their 40's whereas they have been able to win awards in the best supporting actress category in their early 40's and close to middle-age, starting from 1980s. It can be suggested that actors also in the second half of their 40's were able to receive awards in the best supporting actor category in 1990s and 2000s.

Research findings have shown that there were significant differences between the mean ages of best actress and best supporting actress; best actress and best actor; best supporting actress and best supporting actor. It was observed that the difference between the mean ages of best supporting actress and best supporting actor was statistically less significant than the difference between the mean ages of best actress and best supporting actress with best actress and best actor.

From 1960s to this day, the mean age of actors (38 years) has been eight years higher than the mean age of actresses (30 years) among the award winning actors and actresses. In the best supporting actress and best supporting actor categories, mean age of the actors ( 45 years) has been 6 years higher than the mean age of actresses (39 years) since the beginning of the festival. It was detected that the mean age difference of actors and actresses in best actor-actress categories was higher than the mean age difference of best supporting actor-actress categories. In this context, it was concluded that actresses acted in lead roles at younger ages than actors and they were considered appropriate for supporting roles in their advanced age. 
Research results show that the mean age of award-winning actors was higher than the mean age of award-winning actresses in every category under consideration and women received awards at earlier ages than men, as is the case with the studies of Lauzen (2013) and Markson \& Taylor (1993). In this context, it can be suggested that sexist approaches lead to double jeopardy for actresses in advanced ages and their professional career is constricted.

\section{REFERENCES}

Almerico, G.M. \& Thompson, F.H. (1989). The Portrayal of Elderly in US Print Media. Reading, 23 (2), 98-104.

Baybora, D. (2010). Çalışma Yaşamında Yaş Ayrımcılığı ve Amerika Birleşik Devletleri'nde Yaş Ayrımcılığı Düzenlemesi Üzerine. Çalışma ve Toplum, 1, 33-58.

Chappell, N. \& Havens, B. (1980). Old and Female: Testing Double Jeopardy Hypothesis. Sociological Quaterly, 21, 157-171.

Cohen, H.L. (2002). Developing Media Literacy Skills to Challenge Television's Portrayal of Older Women. Educational Gerontology, 28, 599-620

Bazzini, D.G., McIntosh, W.D., Simith S.M., Cook, S. \& Harris, C. (1997). The Aging

Woman in Popular Film: Underrepresented, Unattractive, Unfriendly and Unintelligent. Sex Roles: A Jounal of Research, 36 (7-8), 531-543.

Cuddy A.J \& Fiske, S.T. (2004). Doddering But Dear: Process, Content and Function. In (Todd Nelson ed.), Stereotyping, Prejudice against Older People (3-26). USA: MIT Press

Çelenk, S. (2010). Ayrımcılık ve Medya. In (Bülent Çaplı, Hakan Tuncel eds.) Televizyon Haberciliğinde Etik (211-228). Ankara: İlef

De Pater, I, E., Judge T, A. \& Scott, B.A. (2014). Age, Gender and Compensation: A Study of Hollywood Movie Stars. Journal of Management Inquiry. doi: 10.1177/1056492613519861, 1-14.

Dupâquier, J. (2006). Vieillesemnt de la Population dans le Monde. Rayonnement de la CNRS,

bulletin no: 42. Retrieved April 20, $\quad 2014$ from http://www.rayonnementducnrs.com/bulletin/b2/vieillissement.pdf.

Geray, H. (2006). Toplumsal Araştırmalarda Nicel ve Nitel Yöntemlere Giriş. Ankara: Siyasal.

Gerbner, G. (1994). Aging as a social role: The lessons of television. Retrieved December 14 ,

2013 from http://www.asc.upenn.edu/gerbner/Asset.aspx?assetID=2066.

Gül, İ.I \& Karan, U. (2011). Ayrımcıllk Yasağı Kavram, Hukuk, İzleme ve Belgeleme. İstanbul:İstanbul Bilgi Üniversitesi Yayınlar1. Retrieved August 10, 2013 from http://insanhaklarimerkezi.bilgi.edu.tr/docs/Ayrimcilik_Yasagi_Kavram_Hukuk_Izle me_ve_Belgeleme.pdf.

HelpAge (2011). On the Edge. Retrieved May 2, 2014 from www.helpage.org/download/4e8c29f3cf853/.

Karasar, N. (2007). Bilimsel Araştırma Yöntemi. Ankara: Nobel

Macnicol, J. (2006). Age discrimination: An Historical and Comtemporary Analysis. UK: Cambridge University Press.

Harwood, J. (2000). Sharp! Lurking Incoherence in a Television Portrayal of an Older Adult. Journal of Language and Social Psychology, 19 (1), 110-140.

HelpAge (2011). Discrimination in Old Age: Multiple, Cumulative and on the Increase. Retrieved

April 20, $2014 \quad$ from http://social.un.org/ageing-workinggroup/documents/HelpAge \%20briefing\%20discrimination\%20in\%20old\%20age $\% 20$ Aug\%2011.pdf.

Lagacé, M. (Ed). (2010). Agisme Comprendre et Changer le Regard Social sur le Vieillissement. Québec: Presse de l'Université Laval.

Lauzen, M. (2013). It's a Man's (celluloid) World: On-Screen Representations of Female characters in Top 100 Films on 2013. Retrieved May $15, \quad 2014$ from http://womenintvfilm.sdsu.edu/files/2013_It's_a_Man's_World_Report.pdf.

Lincoln, A., E. \& Allen, M. P. (2004). Double Jeopardy in Hollywood: Age and Gender in the Careers of Film Actors, 1926-1999. Sociological Forum, 19 (4), 611-631. 
Markson E.W \& Taylor, C.A. (1993). Real versus Reel World. Women \& Therapy, 14 (1-2), 157-172.

Markson E.W \& Taylor, C.A. (2000). The Mirror Has Two Faces. Aging and Society, 20, 137-160.

Nelson, T.D. (2011). Ageism. The Strange Case of Prejudice against Older You. In R.L. Wiener $\quad \&$ S.L. Willborn (eds), Disability and aging discirimination (37-47). $\quad$ New York: Springer.

Onur, B. (2011). Gelişim Psikolojisi. Ankara: İmge.

Pellisier, J. (2009). Agisme et Stéréotypes. Vie et Vieillissement, 7 (2), 4-8.

Peterson, R.T. (1992). The Depiction of Senior Citizens in Magazine Advertisements: A Content Analysis. Journal of Business Ethics, 11, 701-706.

Pilote, C. (2010). Avis sur l'âgisme envers les aînés: Etat de la situation. Québec: Conseil des ânés du Québec. Retrieved January 24, 2014 from https://www.uclouvain.be/cps/ucl/doc/aisblgenerations/documents/DocPart_Etud_AgismeQuebec.pdf.

Rahtz, D.R, Sirgy, M.J. \& Meadow, H.L. (1997). The Elderly Audience: Correlates of Television Orientation. Journal of Advertising, 18 (3), 9-20.

Robinson, T. \& Anderson, C. (2006). Older Characters in Children's Animated Programs: A Content Analysis of Their Portrayal. The Journal of Broadcasting \& Electronic Media, 50

(2), 287-304.

Robinson, T., Callister, M., Magoffin, D. \& Moore, J. (2007). The Portrayal of Older Characters

in Disney Animated Films. Journal of Aging, 21 (3), 203-213.

Rochman, J. \& Tremblay, D. G. (2010). Le Soutient à la Participation des Aînés et le Programme "Ville Amie des Aînés" (Note de Recherche no: 2010-5). Montreal: Univeristé de

Québec. Retrieved January $24, \quad 2014$ from http://benhur.teluq.uquebec.ca/SPIP/aruc/IMG/pdf_ARUC-NR10-05-2.pdf.

Roy, A. Harwood, J. (1997). Underrepresented, Positively Portrayed: Older Adults in Television

Commercials. Journal of Applied Communication Research, 25, 39-56.

Sedick, S. \& Ross, V. (2011). Older People's Portrayal in the Print Media: Implications for Intergenerational Relations. Journal of Psychology in Africa, 21 (4), 549-554.

Signorielli, N. (2004). Aging on Television: Messages Relating to Gender, Race and Occupation

in $\quad$ Prime Time. Journal of Broadcasting \& Electronic Media, 48 (2), 279-301.

Smeaton, D. \& Vegeris, S. (2009). Older People Inside and Outside the Labour Market (Equality and Human Rights Commission Research Report no: 22). Retrieved February

$22, \quad 2013$

http://www.equalityhumanrights.com/sites/default/files/documents/research/22._older people_inside_and_outside_the_labour_market_a_review.pdf.

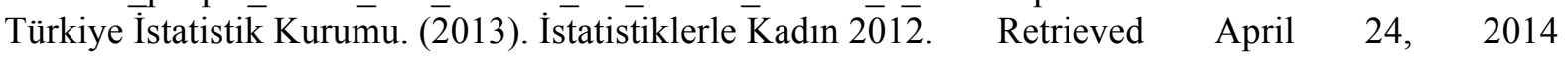
from http://www.tuik.gov.tr/PreHaberBultenleri.do?id=13458.

Türkiye İstatistik Kurumu. (2014). İstatistiklerle Yaşlılar 2013. Retrieved April 24, 2014 from http://www.tuik.gov.tr/PreHaberBultenleri.do?id=16057.

Samorodov, A. (1999). Ageing Labour Markets for oldres workers (Empoyment and training paper). Geneva: ILO.

Sontag, S. (1972). The Double Standard of Aging. Saturday Review of the Society, 23, 29-38.

Saucier, M. G. (2004). Midlife and Beyond: Issues for aging Women. Journal of Conseling \&

Development, 82, 420-425.

United Nations. (2007). World Economic and social survey 2007 development in an ageing world. New York: Author. Retrieved June 20, 2013 from http://www.un.org/esa/analysis/wess/wess2007files/wess2007.pdf.

World Healt Organization. (1972). Psychogeriatrics (Technical Report No: 507). France: Author. Retrieved June 20, 2013 from http://whqlibdoc.who.int/trs/WHO_TRS_507.pdf.

Union Eurpéenne. (2012). Contribution de l'UE au Vieillissement Actif et à la Solidarité Intergénérationnelle. Belgium: Auteur.

United Nations. (1983). Vienna international plan of action on ageing. New York: Author. Retrieved August 11, $\quad 2013$ from http://www.un.org/es/globalissues/ageing/docs/vipaa.pdf. 
United Nations Population Fund \& HelpAge International. (2012). Ageing in the twenty-first century: A celebration and a challenge. USA: Author.Retrieved June 14, 2013 from http://www.unfpa.org/webdav/site/global/shared/documents/publications/2012/ Ageing-

Report_full.pdf.

World Healt Organization. (2002). Active Aging a Policy Framework. Spain: Author.

World Healt Organization. (2007). Global age-friendly cities: A guide. France: Author. Retrieved July 22, 2013 from http://www.who.int/ageing/publications/active_ageing/en/.

World Healt Organization. (2012). Ageing and health. Retrieved July 23, 2013 from http://whqlibdoc.who.int/hq/2012/WHO_DCO_WHD_2012.1_eng.pdf.

Zahidi, S. (2012). Women and Ageing. In Beard, J.R, Biggs, S., Bloom, D.E., Fried, L.P., Hogan, P., Kalache, A. \& Olshansky, S.J. (Eds). Global Population ageing: Peril or

promise?. Geneva: World Economic Forum. Retrieved June 14, 2013 from http://www3.weforum.org/docs/WEF_GAC_GlobalPopulationAgeing_Report_2012. pdf

Zhang, Y.B., Harwood, J., Williams, A., Ylanne-McEven, V., Wadleigh, P.M \& Thimm, C. (2006). The Portrayal of Older Adults in Advertising a Cross-national Review. Journal

of Language and Social Psychology, 25 (2), 264-282.

http://www.beyazperde.com/dosyalar/sinema/dosya-50773/.

http://www.altinportakal.org.tr/festival/festival-tarihcesi/. 